\title{
Morphological Characteristics and Biological Maturation of Brazilian and Portuguese Gymnasts
}

\author{
Características Morfológicas y Maduración Biológica de Gimnastas Brasileñas y Portuguesas
}

\author{
Amanda Batista; Rui Garganta \& Lurdes Ávila-Carvalho
}

\begin{abstract}
BATISTA, A.; GARGANTA, R. \& ÁVILA-CARVALHO, L. Morphological characteristics and biological maturation of Brazilian and Portuguese gymnasts. Int. J. Morphol., 37(2):561-567, 2019.

SUMMARY: The morphological characteristics and biological maturation are among the more important factors in the performance in the Rhythmic Gymnastics. Thus, the aims of the present study were: (1) identify the training, morphological and biological maturation characteristics in elite Brazilian and Portuguese gymnasts; (2) compare these characteristics across groups. The Brazilian Portuguese National Team (13 gymnasts) were studied. Anthropometric and body composition measurements were performed. For analysis of biological maturation, the sexual (pubertal stages and age at menarche) and somatic (offset maturational) maturation were evaluated. The training data were collected by interviewing. For the statistical analysis, Mann-Whitney test was applied. The somatotype and calculation of its components were performed according to the Health-Carter method thought of the MER Goulding Software Development. Brazil and Portugal National Teams presented similar training volume and training onset, however Brazilian gymnasts had higher age and years of practice in Rhythmic Gymnastics than Portuguese gymnasts. Brazilian had higher body mass; height; lower limb length; triceps, subscapular and abdominal skinfolds; relaxed arm and thigh girths; and endomorphy somatotype component than Portuguese. The groups showed different somatotypes: Brazilian (endomorphic ectomorph) and Portuguese (balanced ectomorph), although without statistical significance. The groups demonstrated a delay in maturational development. Similar breast (stages 3 and 4 ) and pubic hair (stages 2 and 3) development were verified. In total, $84.6 \%$ of gymnasts had reached menarche (15.9 \pm 2.6 years) and all gymnasts had reached the age at peak height velocity (14.9 \pm 1.2 years). The distance and age at peak height velocity were higher in Brazilian than in Portuguese.
\end{abstract}

KEY WORDs: Rhythmic gymnastics; Gymnasts; Anthropometry; Body composition; Biological Maturation.

\section{INTRODUCTION}

In Rhythmic Gymnastics (RG), specific morphological characteristics, including somatic dimensions, somatotype and body composition have been considered as contributing factors to the individual high level physical performance (Douda et al., 2008; Ávila-Carvalho et al., 2013; Tringali et al., 2014; Arriaza et al., 2016). The rhythmic gymnasts are characterized by low body mass and body fat, narrow and thin hips, long and thin limbs, and an ectomorphic somatotype (Klentrou \& Plyley, 2003; Douda et al.; ÁvilaCarvalho et al., 2012; Camargo et al., 2014; Kritikou et al., 2017).

In this sense, the gymnasts attempt to stay their morphological characteristics within the standards required by the sport (Camargo et al.). These aesthetic aspects entail a better execution of specific RG movements Irurtia Amigó et al. (2009) and moreover, they are valued and subjectively considered in the competitions (Ávila-Carvalho et al., 2013).
The perception of body image also is an essential factor of the psychological well-being of gymnasts (Vernetta et al., 2011).

Morphological characteristics of rhythmic gymnasts are determined by different factors, such as genetic aspects, training level, specific nutritional plans (Tringali et al.) and also the maturity status (Malina et al., 2016). Several studies (Georgopoulos et al., 2002; Thomis et al., 2005; Beunen \& Malina, 2007; Ávila-Carvalho et al., 2013; Malina et al., 2013; Purenovic-Ivanovic et al., 2017) indicate that gymnasts have a late in pubertal stages, age at menarche and age at peak height velocity (PHV), especially in elite gymnasts.

Therefore, the aims of the present study were: (1) identify the training, morphological and biological maturation characteristics in elite Brazilian and Portuguese gymnasts; (2) compare these characteristics across groups. 


\section{MATERIAL AND METHOD}

Subjects: 13 rhythmic elite senior gymnasts $(n=13)$ were studied - nine from Brazilian National Team (BNT) and four from Portuguese National Team (PNT).

Ethical Considerations: The study protocol was approved by Ethics Committee of the Faculty of Sport, University of Porto (Portugal), Scientific Committee of Brazil and Portugal Gymnastics Federation. The assessments were performed in accordance with the ethical standards of the Helsinki Declaration.

Morphological characteristics: Anthropometric measurements were obtained according to the protocol established in Anthropometric standardization reference manual (Lohman et al., 1988). All measures were performed at the beginning of each training session by the same trained anthropometrist. Body mass $(\mathrm{kg})$ was measured with a portable bio-impedance scale (Tanita BC558 Ironman Segmental Body Composition Analyzer). Height $(\mathrm{cm})$ and sitting height $(\mathrm{cm})$ were determined using the portable stadiometer Personal Sanny. The lower limb length was estimated based on the difference between standing height and sitting height. Upper limb length was measured with a Segmometer (Rosscraft). All diameters (biacromial, bicristal, humerus and femur) were measured with a SH-108 compass round tips. Relaxed and flexed arm, thigh and calf girths were assessed, using an anthropometric measuring tape Sanny. Triceps, subscapular, suprailiac, abdominal, thigh and calf skinfolds were measured with a Holtain Skinfold Caliper. Furthermore, relative body fat (\%BF) was calculated using gender and age-specific equations. For gymnasts under 18 years, we used the equation developed by Slaughter $\mathrm{et}$ al . (1988) and for gymnasts over 18 years the equation proposed by Siri (1961). Body mass index (BMI) was calculated using the equation: body mass $(\mathrm{kg}) /$ height $^{2}$ (m).

Somatotype: The somatotype and calculation of its components were performed according to the Health-Carter method (Carter \& Heath, 1990).

Biological maturation: For analysis of sexual maturation, the gymnasts performed a self-assessment to determine their pubertal stage (Tanner, 1962) through the five phases of development of secondary sexual characteristics: breasts and pubic hair. Menarcheal status and age at menarche (retrospective method) were obtained by questionnaire. To infer, indirectly, the somatic maturation, we used the maturational offset (Mirwald et al., 2002), that it is an estimate of the distance to which an individual is of age at which will occur the peak height velocity (PHV). The value refers age and therefore, it is expressed in years, for more (+) or for less (-). The predicted age at PHV was the difference between chronological age and maturity offset.

Additional data: Chronological age, age of training volume were collected using questionnaires.

Statistical Procedures: Statistical analysis was performed using the Statistical Package for Social Sciences (SPSS 23.0). The significance level was set at $5 \%$. Descriptive statistics were performed using the mean and standard deviation. We applied Mann-Whitney non-parametric test to compare the PNT and BNT. Somatotype calculations and their graphical displays in the somatocharts were done in the MER Goulding Software Development.

\section{RESULTS}

In the training characteristics, Table I shows that BNT and PNT had similar training volume and training onset. However, BNT was significantly older $(\mathrm{p}=0.003)$ and with more years of practice in $\mathrm{RG}(\mathrm{p}=0.006)$ than PNT.

BNT presented higher values in all anthropometrics measurements than PNT (Table I), although significant differences were found only in $44.4 \%$ of variables: body mass; height; lower limb length; skinfolds triceps, subscapular, abdominal; girths relaxed arm and thigh. The same happened to the body composition analysis. We also observed higher values in all variables in BNT, although no significant differences were found in \% BF and BMI.

In the somatotype components, significant differences were observed in the endomorphy component and similar values were found in the mesomorphy and ectomorphy components.

The morphological profile of BNT and PNT (Fig. 1) shows a clear difference in the groups. BNT achieved above average values and higher than PNT in all morphological variables, except in femur diameter, where the values were similar in both groups. Furthermore, PNT was below average in $95.7 \%$ of variables.

The somatocharts by National Teams are shown in Figure 2. BNT (3.0-2.0-3.6) showed an endomorphic ectomorph somatotype and PNT (2.3-2.1-3.7) was classified as balanced ectomorph somatotype. However, there were no significant differences in the groups $(\mathrm{F}=2.08$, 
Table I. Training and morphological characteristics of Brazil and Portugal National Team.

\begin{tabular}{|c|c|c|c|c|c|}
\hline \multicolumn{2}{|c|}{ Variables } & General $(n=13)$ & $\operatorname{BNT}(n=9)$ & PNT $(n=4)$ & $\mathrm{p}$ value \\
\hline \multicolumn{2}{|l|}{ Age (years) } & $19.2 \pm 2.9$ & $21.1 \pm 1.8$ & $16.5 \pm 1.2$ & $0.003^{*}$ \\
\hline \multicolumn{2}{|c|}{ Training volume (hours/we ek) } & $35.5 \pm 1.7$ & $36.0 \pm 0.0$ & $34.5 \pm 3.0$ & 0.503 \\
\hline \multicolumn{2}{|c|}{ Training onset (years) } & $6.9 \pm 2.2$ & $6.8 \pm 2.5$ & $7.0 \pm 1.2$ & 0.872 \\
\hline \multicolumn{2}{|c|}{ RG practice (years) } & $12.4 \pm 3.4$ & $14.0 \pm 2.4$ & $8.8 \pm 2.2$ & $0.006^{*}$ \\
\hline \multicolumn{2}{|l|}{ Body Mass (kg) } & $51.4 \pm 4.6$ & $53.1 \pm 4.3$ & $47.7 \pm 2.7$ & $0.034^{*}$ \\
\hline \multicolumn{2}{|l|}{ Height $(\mathrm{cm})$} & $163.3 \pm 4.4$ & $164.9 \pm 3.4$ & $159.7 \pm 4.7$ & $0.050^{*}$ \\
\hline \multicolumn{2}{|c|}{ Upper limb Length $(\mathrm{cm})$} & $69.9 \pm 2.4$ & $70.0 \pm 2.1$ & $69.6 \pm 3.1$ & 0.940 \\
\hline \multicolumn{2}{|c|}{ Lower limb Length $(\mathrm{cm})$} & $80.0 \pm 3.1$ & $81.3 \pm 1.7$ & $77.2 \pm 3.7$ & $0.050^{*}$ \\
\hline \multirow{6}{*}{ Skinfolds (mm) } & Triceps & $10.2 \pm 3.6$ & $11.6 \pm 3.5$ & $7.0 \pm 1.0$ & $0.011^{*}$ \\
\hline & Subscapular & $6.9 \pm 1.5$ & $7.6 \pm 1.3$ & $5.3 \pm 0.5$ & $0.006^{*}$ \\
\hline & Suprailiac & $9.5 \pm 1.6$ & $9.8 \pm 1.7$ & $8.9 \pm 1.4$ & 0.260 \\
\hline & Abdominal & $9.1 \pm 2.2$ & $10.0 \pm 1.9$ & $7.0 \pm 1.2$ & $0.020^{*}$ \\
\hline & Thigh & $13.7 \pm 2.5$ & $14.2 \pm 2.5$ & $12.7 \pm 2.5$ & 0.260 \\
\hline & Calf & $7.6 \pm 2.4$ & $8.2 \pm 2.5$ & $6.2 \pm 1.5$ & 0.199 \\
\hline \multirow{4}{*}{ Girth $(\mathrm{cm})$} & Flexed arm & $25.1 \pm 1.6$ & $25.7 \pm 1.6$ & $23.9 \pm 0.5$ & 0.076 \\
\hline & Relaxed arm & $23.3 \pm 1.9$ & $24.1 \pm 1.8$ & $21.6 \pm 0.2$ & $0.034^{*}$ \\
\hline & Thigh & $47.9 \pm 2.3$ & $48.9 \pm 1.7$ & $45.4 \pm 1.3$ & $0.011^{*}$ \\
\hline & Calf & $34.3 \pm 1.9$ & $34.9 \pm 1.8$ & $33.0 \pm 1.3$ & 0.106 \\
\hline \multirow{4}{*}{ Diameters $(\mathrm{cm})$} & Biacromial & $35.5 \pm 0.9$ & $35.6 \pm 0.9$ & $35.4 \pm 0.8$ & 0.825 \\
\hline & Bicristal & $24.4 \pm 1.6$ & $24.8 \pm 1.8$ & $23.5 \pm 0.4$ & 0.260 \\
\hline & Humerus & $5.3 \pm 0.3$ & $5.3 \pm 0.2$ & $5.3 \pm 0.3$ & 0.825 \\
\hline & Femur & $7.3 \pm 0.4$ & $7.3 \pm 0.5$ & $7.3 \pm 0.1$ & 0.710 \\
\hline \multirow{3}{*}{$\begin{array}{l}\text { Somatotype } \\
\text { components }\end{array}$} & Endomorphy & $2.8 \pm 0.6$ & $3.0 \pm 0.6$ & $2.3 \pm 0.2$ & $0.029 *$ \\
\hline & Mesomorphy & $2.0 \pm 0.5$ & $2.0 \pm 0.6$ & $2.1 \pm 0.3$ & 0.295 \\
\hline & Ectomorphy & $3.6 \pm 0.5$ & $3.6 \pm 0.6$ & $3.7 \pm 0.6$ & 0.216 \\
\hline Body & \% Body Fat (BF) & $15.7 \pm 3.3$ & $15.1 \pm 2.1$ & $13.2 \pm 1.4$ & 0.199 \\
\hline Composition & BMI $\left(\mathrm{kg} / \mathrm{m}^{2}\right)$ & $19.3 \pm 1.0$ & $19.5 \pm 1.1$ & $18.7 \pm 0.6$ & 0.260 \\
\hline
\end{tabular}

- BNT: Brazil National Team; PNT: Portugal National Team; BMI: body mass index; * $\mathrm{p} \leq 0.05$ : significant differences.

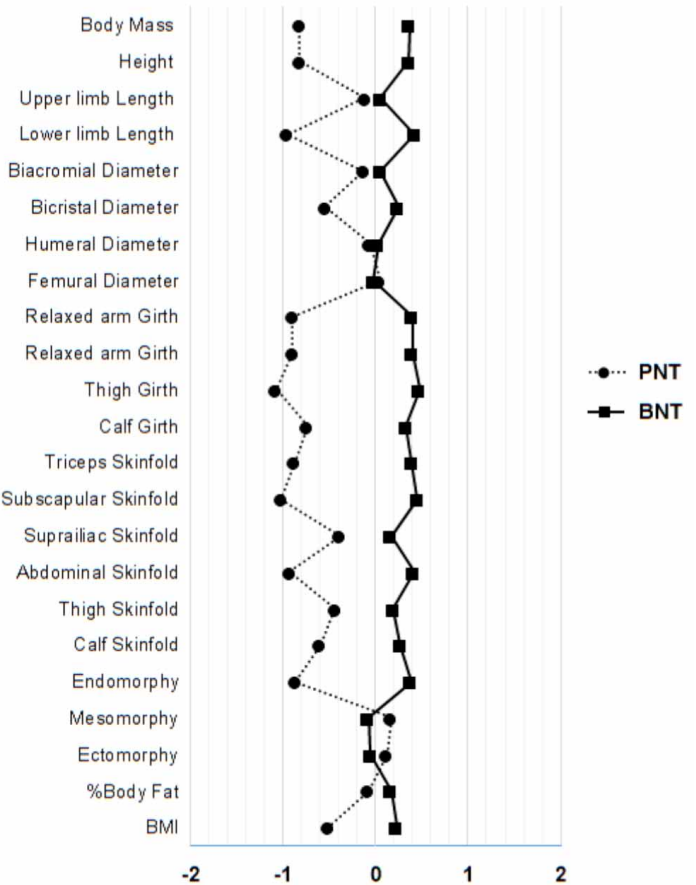

Fig. 1. Morphological profile of Brazil and Portugal National Team based in the scores Z. BNT: Brazil National Team; PNT: Portugal National Team. $\mathrm{p}=0.175)$. The gymnasts from BNT were distributed in profiles central $(22 \%)$; endomorph-ectomorph $(33 \%)$ and balanced ectomorph $(44 \%)$. On the other hand, the gymnasts from PNT were distributed in profiles mesomorphic ectomorph $(25 \%)$ and balanced ectomorph (75\%). Thus, $53.9 \%$ of the individual somatotypes of the gymnasts sample were classified in a balanced ectomorph profile.

Table II presents the maturation data of Brazilian and Portuguese gymnasts. There were no significant differences in the groups in the breast $(\mathrm{p}=0.199)$ and pubic hair $(\mathrm{p}=0.148)$ development. The gymnasts from both groups were mainly in stages 3 and $4(84.7 \%)$ in breast development, and in stages 2 and $3(84.6 \%)$ in pubic hair development. $84.6 \%$ of gymnasts had reached menarche (15.9 \pm 2.6 years). Further, all gymnasts had reached the age at peak height velocity $(14.9 \pm 1.2$ years). The age at menarche, distance of PHV ( $\mathrm{p}=0.003)$ and age at PHV $(\mathrm{p}=0.003)$ were higher in BNT than in PNT. However, significant differences were not found in age at menarche $(\mathrm{p}=0.073)$, probably due the reduced Portuguese sample, once that only two gymnasts $(50 \%)$ reported menarche. 

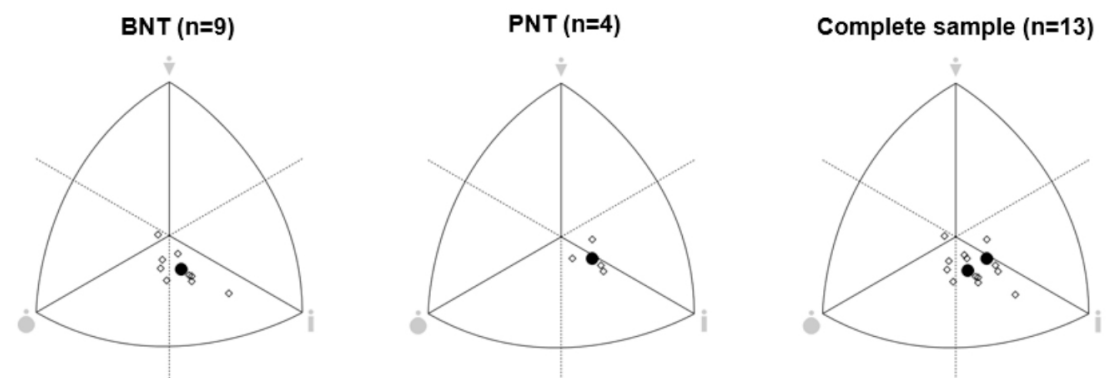

Fig. 2. Somatocharts of Brazil and Portugal National Team. -: endomorphy; : mesomorphy; : ectomorphy; The quadrilaterals are individual somatotypes and the circle is mean profile; BNT: Brazil National Team; PNT: Portugal National Team.

Table II. Summary table of biological maturation of Brazil and Portugal National Team.

\begin{tabular}{|c|c|c|c|c|c|c|c|}
\hline \multirow[b]{3}{*}{ National Team } & \multicolumn{6}{|c|}{$\begin{array}{c}\text { Sexual Maturation } \\
\text { Pubertal stages analysis (number and \% of gymnasts) }\end{array}$} & \multirow[b]{3}{*}{ PH5 } \\
\hline & \multicolumn{3}{|c|}{ Breast (B) } & \multicolumn{3}{|c|}{ Pubic hair (PH) } & \\
\hline & B3 & B4 & B5 & $\mathrm{PH} 2$ & PH3 & PH4 & \\
\hline BNT $(n=9)$ & $3(33.3 \%)$ & $4(44.5 \%)$ & $2(22.2 \%)$ & $3(33.3 \%)$ & $4(44.5 \%)$ & $1(11.1 \%)$ & $1(11.1 \%)$ \\
\hline PNT $(n=4)$ & $3(75.0 \%)$ & $1(25.0 \%)$ & - & $1(25.0 \%)$ & $3(75.0 \%)$ & - & - \\
\hline Total $(n=13)$ & $6(46.2 \%)$ & $5(38.5 \%)$ & $2(15.3 \%)$ & $4(30.8 \%)$ & $7(53.8 \%)$ & $1(7.7 \%)$ & $1(7.7 \%)$ \\
\hline \multicolumn{8}{|c|}{ Menarche } \\
\hline National Team & \multirow{2}{*}{\multicolumn{2}{|c|}{$\begin{array}{c}\text { Chronological age } \\
21.1^{*} \pm 1.8\end{array}$}} & \multicolumn{3}{|c|}{ Number and $\%$ of gymnasts } & \multicolumn{2}{|c|}{ Age at Menarche } \\
\hline BNT (n=9) & & & \multicolumn{3}{|c|}{$9(100 \%)$} & \multicolumn{2}{|c|}{$16.6 \pm 2.2$ years } \\
\hline PNT $(n=4)$ & \multicolumn{2}{|c|}{$16.5 * \pm 1.2$} & \multicolumn{3}{|c|}{$2(50 \%)$} & \multicolumn{2}{|c|}{$13.0 \pm 1.4$ years } \\
\hline Total $(n=13)$ & \multicolumn{2}{|c|}{$19.7 \pm 2.8$} & & $1(84.6 \%)$ & & $15.9 \pm 2.6$ & ears \\
\hline \multicolumn{8}{|c|}{ Maturational) } \\
\hline National Team & \multicolumn{2}{|c|}{ Chronological age } & \multicolumn{3}{|c|}{ Distance of PHV } & \multicolumn{2}{|c|}{ Age at PHV } \\
\hline BNT $(n=9)$ & \multicolumn{2}{|c|}{$21.1 * \pm 1.8$} & \multicolumn{3}{|c|}{$2.8^{*} \pm 1.1$ years } & \multicolumn{2}{|c|}{$17.9 * \pm 1.1$ years } \\
\hline PNT $(n=4)$ & \multicolumn{2}{|c|}{$16.5 * \pm 1.2$} & \multicolumn{3}{|c|}{$0.5^{*} \pm 0.8$ years } & \multicolumn{2}{|c|}{$15.6 * \pm 0.5$ years } \\
\hline Total $(n=13)$ & \multicolumn{2}{|c|}{$19.7 \pm 2.8$} & \multicolumn{3}{|c|}{$4.7 \pm 1.7$ years } & \multicolumn{2}{|c|}{$14.9 \pm 1.2$ years } \\
\hline
\end{tabular}

- BNT: Brazil National Team; PNT: Portugal National Team; PHV: peak height velocity; ${ }^{*} \mathrm{p} \leq 0.05$ : significant differences

\section{DISCUSSION}

BNT gymnasts had more time to practice in $\mathrm{RG}$ (14.0 \pm 2.4 years) and they were older $(21.1 \pm 1.8$ years) than PNT gymnasts (age 16.5 \pm 1.2 years and practice of $8.8 \pm 2.2$ years). The training volume also was higher in BNT (36.0 \pm 0.0 hours/week) than PNT (34.5 \pm 3.0 hours/week), despite without statistical significance. Further, both groups present a training load (hours/week) according to international recommendations that suggest more than 30 hours/week (Georgopoulos et al., 2002; Malina et al., 2013). On the other hand, Ávila-Carvalho et al. (2013) observed a higher training volume in elite senior gymnasts $(39.5 \pm 7.0$ hours/week for young gymnasts and $41.4 \pm 5.9$ hours/week for adult gymnasts). The authors also analyzed the training volume in some RG studies with elite gymnasts done in previous years and concluded that there was an increase training in hours that starts at the second half of first decade of this century. di Cagno et al. (2008) found similar training volume values $(39.8 \pm 0.6$ hours/week) in elite senior gymnasts (17.8 \pm 1.5 years). According to Berlutti et al. (2010), the gymnasts who participated in the European Championship of 1986 trained 21.7 hours/week and in 2008, 36 hours/week. These data demonstrate a tendency to increase the training volume over the recent years, probably due to the high physical and technical requirements in RG (Ávila-Carvalho et al., 2013).

The morphological characteristics are one of the important factors in the performance in RG (Douda et al.; Ávila-Carvalho et al., 2013; Tringali et al.; Arriaza et al.), once that the success in this sport is strongly influenced by visual appeal and body aesthetics (Klentrou \& Plyley; ÁvilaCarvalho et al., 2013). 
Several authors have proposed that the most common somatotype profile in RG is the balanced ectomorph, which implies a dominance of the ectomorphic component, similar prevalence and moderate values in the remaining components (Irurtia Amigó et al.; Romero Quintero et al., 2011; Camargo et al.; Kritikou et al.). However, there are studies that verified different somatotypes in gymnasts: the mesomorph-ectomorph as well as the central somatotype (Vernetta et al.; Arriaza et al.), mesomorphic ectomorph (Irurtia Amigó et al.) and even the balanced endomorph Romero Quintero et al. In our study, BNT showed an endomorphic ectomorph somatotype (3.0-2.0-3.6), i.e., it included ectomorph gymnasts, the majority of whom had an accentuated endomorphic component. On the other hand, PNT presented a balanced ectomorph somatotype (2.3-2.1$3.7)$, i.e. the ectomorphy component was dominant. In total, $53.9 \%$ of the individual somatotypes of the gymnasts sample were classified in a balanced ectomorph profile: $44 \%$ from BNT and $75 \%$ from PNT.

The groups analyzed in our study showed different morphological characteristics. The BNT presented higher values in all anthropometric and body composition variables than PNT, probably due to being older and possible genetic factors.

The BNT (21.1 \pm 1.8 years) had similar values of body mass to the some studies with elite gymnasts older than 18 years (Georgopoulos et al., 1999; Irurtia Amigó et al.; Berlutti et al.; Ávila-Carvalho et al., 2013). The same was observed when we compared the body mass of PNT (16.5 \pm 1.2 years) with studies about gymnasts under the age of 18 years (Georgopoulos et al., 2002; di Cagno et al.; Arriaza et al.). On the other hand, BTN and PNT presented lower height values than the gymnasts presented in the same studies. Thus, we verified higher BMI values in both groups than in previously reported studies, except in Arriaza et al. that the gymnasts had BMI of $20.1 \mathrm{~kg} / \mathrm{m}^{2}$.

Few studies with anthropometric measurements including lengths, girth, diameters and skinfolds were found, probably by the temporal and operational difficulty in performing this type of assessment in elite gymnasts.

BNT and PNT had lower values of thigh girth than the elite senior gymnasts studied by Ávila-Carvalho et al. (2013). BNT and PNT presented lower values of bicristal, humerus and femur diameters; and higher values of biacromial diameters than elite senior gymnasts in a study performed by di Cagno et al. Furthermore, these authors also analyzed the sum of triceps, subscapular and suprailiac skinfolds $(21.3 \pm 2.4 \mathrm{~mm})$ and found higher values than PNT $(21.2 \pm 2.0 \mathrm{~mm})$ and lower than BNT $(29.0 \pm 5.4 \mathrm{~mm})$.
In the previously reported studies with elite senior gymnasts, there were studies with lower \%BF: $11.2 \pm 1.0 \%$ (di Cagno et al.); $11.3 \pm 1.4 \%$ (Irurtia Amigó et al.); $12.0 \pm 1.5$ $\%$ (Romero Quintero et al.); and other with higher \%BF: $17.6 \pm 3.0 \%$ (Berlutti et al.); and 16.7 $\pm 2.9 \%$ (Ávila-Carvalho et al., 2012), than our study: BNT (15.1 $\pm 2.1 \%)$ and PNT $(13.2 \pm 1.4 \%)$. According to Ávila-Carvalho et al. (2012), $\% \mathrm{BF}$ it is not a measure of success in RG nowadays, although, female gymnasts have lower body mass and \% BF than a reference population (Malina et al., 2016). This sport requires gymnasts to be in good shape and to maintain a thin body type with the lowest possible body fat (PurenovicIvanovic et al.). Klentrou \& Plyley observed that the mean $\% \mathrm{BF}$ of the gymnasts from two nationalities (Greek: $14.3 \pm 0.5 \%$ and Canadian:16.2 $\pm 0.4 \%$ ) was significantly lower than the control subjects (Greek: $21.1 \pm 1.0 \%$ and Canadian: $25.1 \pm 1.3 \%$ ).

Ávila-Carvalho et al. (2012) referred that apparently, in the past, RG gymnasts were younger and thinner than today. The authors believe that the increase on elite gymnast's age means an increase of the longevity career in RG, and this can affect the high level senior gymnasts new body appearance model (Berlutti et al.; Ávila-Carvalho et al., 2012). However, morphological characteristics of rhythmic gymnasts are determined by several factors, such as genetic aspects, training requirements, specific nutritional plans (Tringali et al.) sport season periods where the data are taken (Irurtia et al.) and maturity status (Malina et al., 2016).

Several studies (Georgopoulos et al., 2002; Thomis et al.; Beunen \& Malina; Ávila-Carvalho et al., 2012, 2013; Malina et al., 2013; Purenovic-Ivanovic et al.) indicate that gymnasts have a late in pubertal stages, age at menarche and age at peak height velocity (PHV), especially in elite gymnasts. However, the main indicator of maturation used in studies with gymnasts is the age at menarche, probably because it is a less invasive method, easier application, and without anthropometric measures.

In elite $\mathrm{RG}$ gymnasts, more recent studies showed similar age at menarche (in years): $15.9 \pm 1.3$ (Berlutti et al.); 15.9 \pm 1.4 (Ávila-Carvalho et al., 2012); $14.8 \pm 1.1$ for young and 16.6 \pm 1.2 for adult (Ávila-Carvalho et al., 2013), 15.3 \pm 1.3 (Silva \& Paiva, 2015). In our study, $84.6 \%$ of gymnasts already had reached menarche (15.9 \pm 2.6 years): $100 \%$ from BNT (16.6 \pm 2.2 years) and $50 \%$ from PNT (13.0 \pm 1.4 years). In the study performed by Georgopoulos et al. (1999), the mean age at menarche of gymnasts was significantly delayed from that of their mothers and sisters; was positively correlated to the training intensity and to the difference between

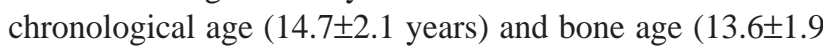
years); and was negatively correlated to body fat. 
The pubertal stages verified in our study showed that the gymnasts were not yet in the mature state. The most gymnasts were in stages 3 and $4(84.7 \%)$ in breast development, and in stages 2 and $3(84.6 \%)$ in pubic hair development. We found similar data to Purenovic-Ivanovic et al. in the pubertal stages (breast development), once that the authors observed in 15 senior gymnasts (17.5 \pm 1.4 years), stages between the phases 3 to 5 (mean 3.8 \pm 0.6 ) and in our study, the gymnasts presented the same range (mean $3.7 \pm 0.8)$.

According to Malina et al. (2004), generally the PHV in girls occurs at about 12 years of age, although the timing of each event (the growth spurt, PHV and termination of growth) is variable among individuals (Malina et al., 2016). In our study, the gymnasts had reached the age at PHV (14.9 \pm 1.2 years), and both groups presented a later age of PHV: $15.6 \pm 0.9$ years $(B N T)$ and $13.7 \pm 0.4$ years $(P N T)$.

Thomis et al. verified that individually fitted growth curves for 13 female gymnasts followed, on average, from 8.7 to 15.5 years, indicating also a later age at PHV compared to a reference general population.

Therefore, according to the maturational data observed in our study, the BNT and PNT showed maturation. Several authors (Georgopoulos et al., 1999; Baxter-Jones et al., 2003; Klentrou \& Plyley; Maïmoun et al., 2014) suggest that the delay in the growth and maturation occurs due to the different factors: nutrition, heredity, state of health, body fat, high volume and intensity training, chronic psychological stress and other. Furthermore, presently available data, point that the sports training, alone do not likely affect maturation and therefore, adult final height was not expected to be affected (Georgopoulos et al., 2002; Baxter-Jones et al.; Beunen \& Malina; Malina et al., 2013).

Although these data are extremely relevant, one of the limitations of the study is the small sample size. The power of the statistical tests is decreased in studies with reduced samples, however, the reality of the sport shows that elite athletes are a restricted group and for that reason, the number is reduced.

As conclusions, BNT and PNT presented similar training volume and training onset, however Brazilian gymnasts had higher age and years of practice in RG than Portuguese gymnasts. The groups showed different morphological characteristics. The older and experienced gymnasts had higher values in all anthropometric and body composition variables, however only the variables body mass; height; lower limb length; triceps, subscapular and abdominal skinfolds; relaxed arm and thigh girths presented significant differences. The groups also showed different somatotypes: BNT (endomorphic ectomorph) and PNT (balanced ectomorph), although without statistical significance. Finally, the groups demonstrated a delay in maturational development. Similar breast (stages 3 and 4) and pubic hair (stages 2 and 3) development were verified. In total, $84.6 \%$ of gymnasts had reached menarche $(15.9 \pm 2.6$ years) all gymnasts had reached the age at peak height velocity (14.9 \pm 1.2 years). The age at menarche, distance and age at PHV were higher in Brazilian than in Portuguese, although significant differences were not found in age at menarche.

\section{ACKNOWLEDGMENTS}

The authors would like to thank the Brazilian and Portuguese Federation of Gymnastics, the gymnasts and coaches that permitted the making of this study possible.

BATISTA, A.; GARGANTA, R. \& ÁVILA-CARVALHO, L. Características morfológicas y maduración biológica de gimnastas brasileñas y portuguesas. Int. J. Morphol., 37(2):561-567, 2019.

RESUMEN: Las características morfológicas y la maduración biológica se encuentran entre los factores más importantes en el rendimiento en la gimnasia rítmica. Por lo tanto, los objetivos del presente estudio fueron: (1) identificar las características de entrenamiento, morfológicas y maduración biológica en las gimnastas brasileñas y portuguesas de élite; (2) comparas estas características entre grupos. Se estudió la Selección Nacional Portuguesa y Brasileña (13 gimnastas). Se realizaron mediciones antropométricas y de composición corporal. Para el análisis de la maduración biológica, se evaluaron las etapas sexuales (etapas de pubertad y edad en la menarquia) y somáticas (edad en el pick de velocidad de altura). Los datos de entrenamiento fueron recolectados mediante entrevistas. Para el análisis estadístico, se aplicó la prueba de Mann-Whitney. El somatotipo y el cálculo de sus componentes se realizaron de acuerdo con el método de Health-Carter, pensado en el desarrollo de software MER Goulding. Los equipos nacionales de Brasil y Portugal presentaron un volumen de entrenamiento y un inicio de entrenamiento similares; sin embargo, las gimnastas brasileñas tenían mayor edad y años de práctica en gimnasia rítmica que las gimnastas portuguesas. Las brasileñas tenían mayor masa corporal; altura; longitud del miembro inferior; pliegues cutáneos del músculo tríceps, músculo subescapular y a nivel abdominal; circunferencia relajada del brazo y del muslo; y el componente somatotípico endomórfico que el portugués. Los grupos eran diferentes somatotipos: brasileñas (ectomórfico endomórfico) y portugués (ectomórfico equilibrada), aunque sin significación estadística. Los grupos demostraron un retraso en el desarrollo madurativo. Se verificó un desarrollo similar del seno (estadios 3 y 4) y del vello púbico (estadios 2 y 3 ). En total, el $84,6 \%$ de las gimnastas alcanzaron la menarquia (15,9 $\pm 2,6$ años) y el 92,3\% de las gimnastas alcanzaron su altura máxima con 17,4 $\pm 1,2$ años. 
La distancia y la edad en la velocidad de alcance de la altura máxima fueron más altas en Brasil que en Portugal.

PALABRAS CLAVE: Gimnasia rítmica; Gimnastas; Antropometría; Composición corporal; Maduración biológica.

\section{REFERENCES}

Irurtia Amigó, A.; Sala, V.; Faciabén, A.; Evrard, M.; Marginet, M. \& Zamora, L. Talla, peso, somatotipo, y composición corporal en gimnastas de élite españolas (gimnasia rítmica) desde la infancia hasta la edad adulta. Apunts Educación Física y Deportes, 64-74, 2009.

Arriaza, E.; Rodríguez, C.; Carrasco, C.; Mardones, C.; Niedmann, L., \& López-Fuenzalida, A. Anthropometric characteristics of elite rhythmic gymnasts. Int. J. Morphol., 34(1):17-22, 2016.

Ávila-Carvalho, L.; Klentrou, P.; Palomero, M. L. \& Lebre, E. Anthropometric profiles and age at menarche in elite group rhythmic gymnasts according to their chronological age. Sci. Sports, 28(4):17280,2013

Ávila-Carvalho, L.; Klentrou, P.; Palomero, M. L. \& Lebre, E. Body composition profile of elite group rhythmic gymnasts. Sci. Gymnast. J., 4(1):21-32, 2012.

Baxter-Jones, A. D. G.; Maffulli, N. \& Mirwald, R. L. Does elite competition inhibit growth and delay maturation in some gymnasts? Probably not. Pediatr. Exerc. Sci., 15(4):373-82, 2003.

Berlutti, G.; Briganti, C.; Pamich, T.; Torrisi, L.; Franco, A.; Morino, G. \& Caldarone, G. Body composition, biological maturation, alimentary habit, anthropometric characteristics in rhythmic gymnastics athletes. From the Florence 1986 European Championships to the Turin 2008 Europian Championships, Twenty years of evolution. Roma, Federazione Ginnastica d'Italia, 2010.

Beunen, G., \& Malina, R. M. Growth and Biologic Maturation: Relevance to Athletic Performance. In: Hebestreit, H. \& Bar-Or, O. (Eds.). The Young Athlete. Oxford, Blackwell Publishing Ltd., 2007. pp.3-17.

Camargo, C. T.; Gomez-Campos, R. A.; Cossio-Bolaños, M. A.; Barbeta, V. J.; Arruda, M. \& Guerra-Junior, G. Growth and body composition in Brazilian female rhythmic gymnastics athletes. J. Sports Sci., 32(19):1790-6, 2014.

Carter, J. E. L. \& Heath, B. H. Somatotyping. Development and Applications. Cambridge, Cambridge University Press, 1990.

di Cagno, A.; Baldari, C.; Battaglia, C.; Guidetti, L. \& Piazza, M. Anthropometric characteristics evolution in elite rhythmic gymnasts. Ital. J. Anat. Embryol., 113(1):29-35, 2008.

Douda, H. T.; Toubekis, A. G.; Avloniti, A. A. \& Tokmakidis, S. P. Physiological and anthropometric determinants of rhythmic gymnastics performance. Int. J. Sports Physiol. Perform., 3(1):41-54, 2008.

Georgopoulos, N. A.; Markou, K. B.; Theodoropoulou, A.; Benardot, D.; Leglise, M. \& Vagenakis, A. G. Growth retardation in artistic compared with rhythmic elite female gymnasts. J. Clin. Endocrinol. Metab., 87(7):3169-73, 2002.

Georgopoulos, N.; Markou, K.; Theodoropoulou, A.; Paraskevopoulou, P.; Varaki, L.; Kazantzi, Z.; Leglise, M. \& Vagenakis, A. G. Growth and pubertal development in elite female rhythmic gymnasts. J. Clin. Endocrinol. Metab., 84(12):4525-30, 1999.

Klentrou, P. \& Plyley, M. Onset of puberty, menstrual frequency, and body fat in elite rhythmic gymnasts compared with normal controls. $\mathrm{Br}$. J. Sports Med., 37(6):490-4, 2003.

Kritikou, M.; Donti, O.; Bogdanis, G. C.; Donti, A. \& Theodorakou, K. Correlates of artistry performance scores in preadolescent rhythmic gymnasts. Sci. Gymnast. J., 9(2):165-77, 2017.

Lohman, T. G.; Roche, A. F. \& Martorell, R. Anthropometric Standardization Reference Manual. Vol. 3. Champaign, Human Kinetics Books, 1988.
Maïmoun, L.; Georgopoulos, N. A. \& Sultan, C. Endocrine disorders in adolescent and young female athletes: impact on growth, menstrual cycles, and bone mass acquisition. J. Clin. Endocrinol. Metab., 99(11):4037-50, 2014.

Malina, R. M.; Ackerman, K. E. \& Rogol, A. D. Growth and the Young Female Athlete. In: Stein, J.; Ackerman, C. \& Stracciolini, L. E. (Eds.). The Young Female Athlete. Cham, Springer, 2016.

Malina, R. M.; Baxter-Jones, A. D.; Armstrong, N.; Beunen, G. P.; Caine, D.; Daly, R. M.; et al. Role of intensive training in the growth and maturation of artistic gymnasts. Sports Med., 43(9):783-802, 2013.

Malina, R.; Bouchard, C. \& Bar-Or, O. Growth, Maturation, and Physical Activity. Vol. 2. Champaign, Human Kinetics, 2004.

Mirwald, R. L.; Baxter-Jones, A. D.; Bailey, D. A. \& Beunen, G. P. An assessment of maturity from anthropometric measurements. Med. Sci. Sports Exerc., 34(4):689-94, 2002.

Purenovic-Ivanovic, T.; Popovic, R. \& Moskovljevic, L. The contribution of pubertal development to performance scores in high-level rhythmic gymnasts. Acta Gymnica, 47(3):122-9, 2017.

Romero Quintero, B.; Palomino Martín, A. \& González Henríquez, J. J. El perfil antropomètric de la gimnàstica rítmica. Apunts Educ. Fís. Esports, (103):48-55, 2011

Silva, M. R. \& Paiva, T. Low energy availability and low body fat of female gymnasts before an international competition. Eur. J. Sport Sci., 15(7):591-9, 2015.

Siri, W. Body Composition from Fluid Spaces and Density. In: Henschel, B. A. (Ed.). Techniques for Measuring Body Composition. Washington D. C., National Academy of Sciences, National Research Council, 1961. pp.223-44.

Slaughter, M. H.; Lohman, T. G.; Boileau, R. A.; Horswill, C. A.; Stillman, R. J.; Van Loan, M. D. \& Bemben, D. A. Skinfold equations for estimation of body fatness in children and youth. Hum. Biol., 60(5):70923, 1988.

Tanner, J. M. Growth at Adolescence. Vol. 2. Oxford, Blackwell Scientific Publications, 1962.

Thomis, M.; Claessens, A. L.; Lefevre, J.; Philippaerts, R.; Beunen, G. P. \& Malina, R. M. Adolescent growth spurts in female gymnasts. $J$. Pediatr., 146(2):239-44, 2005.

Tringali, C.; Brivio, I.; Stucchi, B.; Silvestri, I.; Scurati, R.; Michielon, G.; Alberti, G. \& Venerando, B. Prevalence of a characteristic gene profile in high-level rhythmic gymnasts. J. Sports Sci., 32(14):1409-15, 2014.

Vernetta, M.; Fernández, E.; López-Bedoya, J.; Gómez-Landero, A. \& Oña, A. Estudio relacional entre el perfil morfológico y estima corporal en la selección andaluza de gimnasia rítmica deportiva. Eur. J. Hum. Mov., 26:77-92, 2011.

\section{Corresponding author: Amanda Batista \\ R. Dr. Plácido da Costa 91 \\ 4200-450 \\ Porto \\ PORTUGAL}

Email: amandabatistagrd@yahoo.com.br

Received: 17-09-2018

Accepted: 14-01-2019 